\author{
DEPARTMENT OF THE INTERIOR \\ UNITED STATES GEOLOGICAL SURVEY
}

PREPARED IN COOPERATION WITH THE

COMMONWEALTH OF MASSACHUSETTS

DEPARTMENT OF PUBLIC WORKS

\title{
AEROMAGNETIC MAP OF THE NEW BEDFORD SOUTH QUADRANGLE, BRISTOL COUNTY, MASSACHUSETTS
}

\author{
GEOPHYSICAL INVESTIGATIONS \\ MAP GP-810
}

